\title{
An Estimation of Technical Efficiency of Poultry Farming in Nepal
}

\author{
Nripesh Bahadur Pradhan \\ Student at Central Department of Economics, Tribhuvan University. Email address: \\ nrepes0@gmail.com \\ Nirmal Kumar Raut, PhD \\ Corresponding Author. Dr. Raut is a Lecturer at Central Department of Economics, \\ Tribhuvan University. Email address: nirmal.raut@cdes.tu.edu.np/nimsraut@gmail.com
}

\begin{abstract}
The commercial poultry is growing rapidly in Nepal which requires that efficient level of output that ensures high levels of productivity and profit is produced. The objective of this study is to estimate the technical efficiency of the poultry farming in Nepal and its distribution spatially across the districts. The study utilizes Cobb-Douglas production function to define the structure of the production model and its error term is assumed to follow exponential distribution. Thereafter, using maximum likelihood estimator, parametric approach to Stochastic Frontier Method is applied to the data obtained from Nepal Commercial Poultry Survey 2015. The study finds technical efficiency of 92 percent suggesting high efficiency. Assuming half-normal distribution in the error term, however, yields technical efficiency of 89 percent. Further disaggregation of technical efficiency by districts shows its homogenous distribution across the districts covered in the study. The study, hence, suggests the possibility to increase its production to the level of potential output by improving technical efficiency. One of the various ways to improve technical efficiency is by ensuring high quality inputs both physical and technical to the poultry farms.
\end{abstract}

Keywords: Poultry farming, technical efficiency, stochastic frontier, homogenous

JEL Codes: C21, Q12, Q16

\section{INTRODUCTION}

Raising fowl and other livestock at own backyard is a common trait of Nepalese society. In rural areas, it is natural to find few livestock in each household. It serves as primary source of protein diet and extra income for the household. In developing countries like Nepal where agriculture sector remains a significant contributor to economic growth, the value addition of the livestock sector is quite important. 
Commercial chicken farming is an important source of livelihood. In order to get maximum return from the investment made in the poultry farming, it is important that the farmer produces an efficient output at each process of production from breeding to hatchery (Davey, 1948). For example, if there is a demand for large sized eggs, it would be efficient for the famers to purchase specific breed of chicken that would lay such eggs rather than selecting only large sized eggs to sell in the market. Likewise, there are bunch of other factors/inputs including stock of birds, labour, feed and care that plays an important role in producing efficient level of output.

Essentially, no business can run in full efficiency. Any production process has some by-product which if not commercially utilized may result into waste. This is inefficient which indicates that the resources used in the process of production are underutilized. In poultry farming, for example, by-product like feces if sold as a manure and down feather sold to produce jacket, blanket and pillows will help minimize such waste. It is therefore important to understand the level of efficiency of any production endeavor so that the resource allocation becomes optimal across competing ends. Efficient operation of the businesses including poultry farms helps increasing productivity, lower the cost of production, and increase the scale of profits.

Conceptually, efficiency can be categorized as technical efficiency (technical efficiency), productive efficiency and allocative efficiency. Technical efficiency means process of obtaining the maximum product from a set of resource inputs. A technically efficient intervention produces same or greater output with less of one type of input. Productive efficiency, on the other hand, is attained when output is maximized for a given cost, or the cost is minimized for a given output. Allocative efficiency is global measure of efficiency; this not only considers productive efficiency but also how the outputs are distributed among the members of the society (Palmer \& Torgerson, 1999). In this paper, we discuss technical efficiency of poultry farming in Nepal.

Technical efficiency of the firm determines its ability to produce output with minimum loss of input. It helps government to plan the targeted strategy to improve the deficiencies in the industry. In case of firms, it will highlight the areas that need particular attention such as need of training, quality breed of chicken and better managerial practice that will help improve the efficiency of the firm. Hence, the estimates of the technical efficiency help in designing future policy and strategy. It also helps government to rank the producers according to efficiency level and regulate the industries. For example, tougher regulation could be set for the inefficient industries to discourage the owner from transferring the miss-managed loss onto the customers (Kumbhakar \& Wang, 2010). 
The objective of the study is therefore to understand the technical efficiency of the poultry farming in Nepal. We estimate the technical efficiency both at national and sub-national levels; understanding technical efficiency at district levels highlights the heterogeneity in terms of identifying intensity of constraints faced by poultry industries as well as the need of differential and localized approach to addressing those constraints. We primarily use the data from the Nepal Commercial Poultry Survey 2015 (NCPS 2015) and apply Stochastic Frontier Analysis (SFA) to calculate technical efficiency. Depending upon the distributional assumption made, we find technical efficiency range between 89 and 92 percent and that there is a less heterogeneity in the spatial distribution of technical efficiency.

The rest of the sections are organized as follows. Section 2 provides an overview of poultry farming in Nepal. Section 3 discusses theoretical model. Section 4 reviews some empirical literature. Section 5 explains the data and methods used in the study. Section 6 presents and discusses the results. Section 7 concludes.

\section{COMMERCIAL POULTRY FARMING IN NEPAL}

The commercial poultry farm in Nepal was formally initiated in 1957/58. The government established and operated the central hatchery in Parwanipur with the support of USAID. According to CBS (2016), there are 21956 poultry farms spread in 64 districts of the country. Figure 1 shows the spatial distribution of poultry farms in Nepal by districts.

Figure 1: District-Wise Distribution of Poultry Farms in Nepal

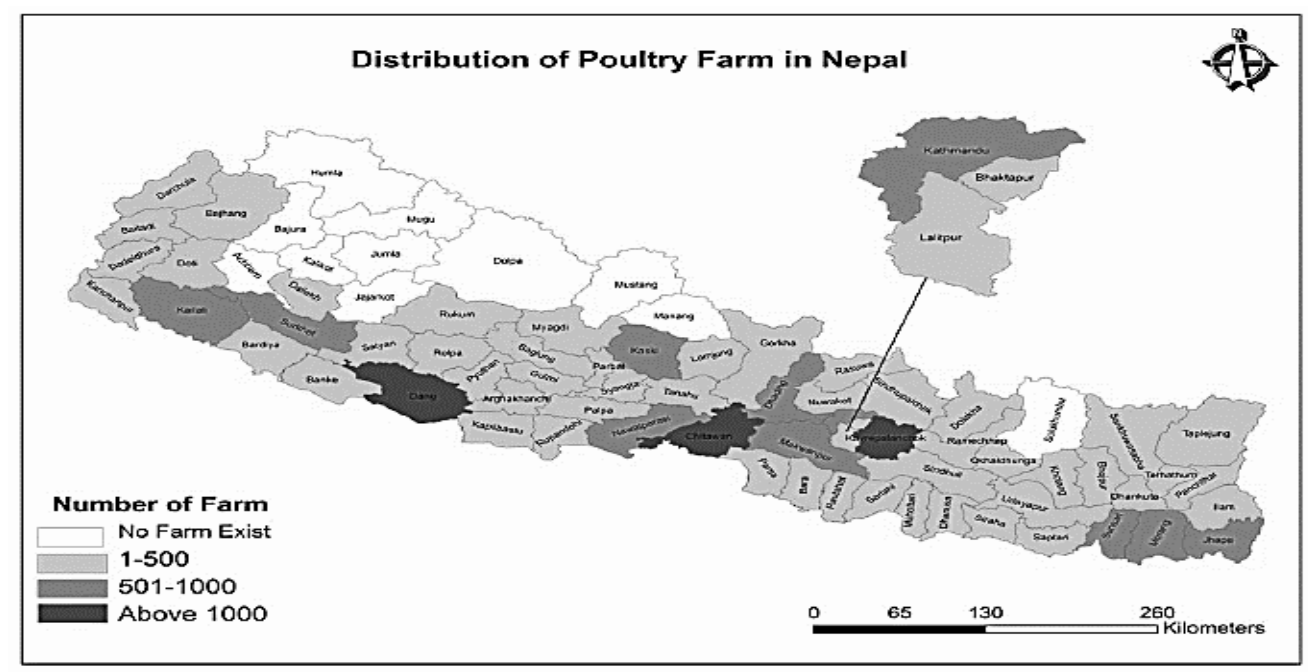

Source: CBS (2016) 
Increase in purchasing power of people have improved the demands of meat products mostly chicken products. This has further incentivized the entrepreneurs to enter or expand the business. One of the advantages of the poultry farming is its low gestation

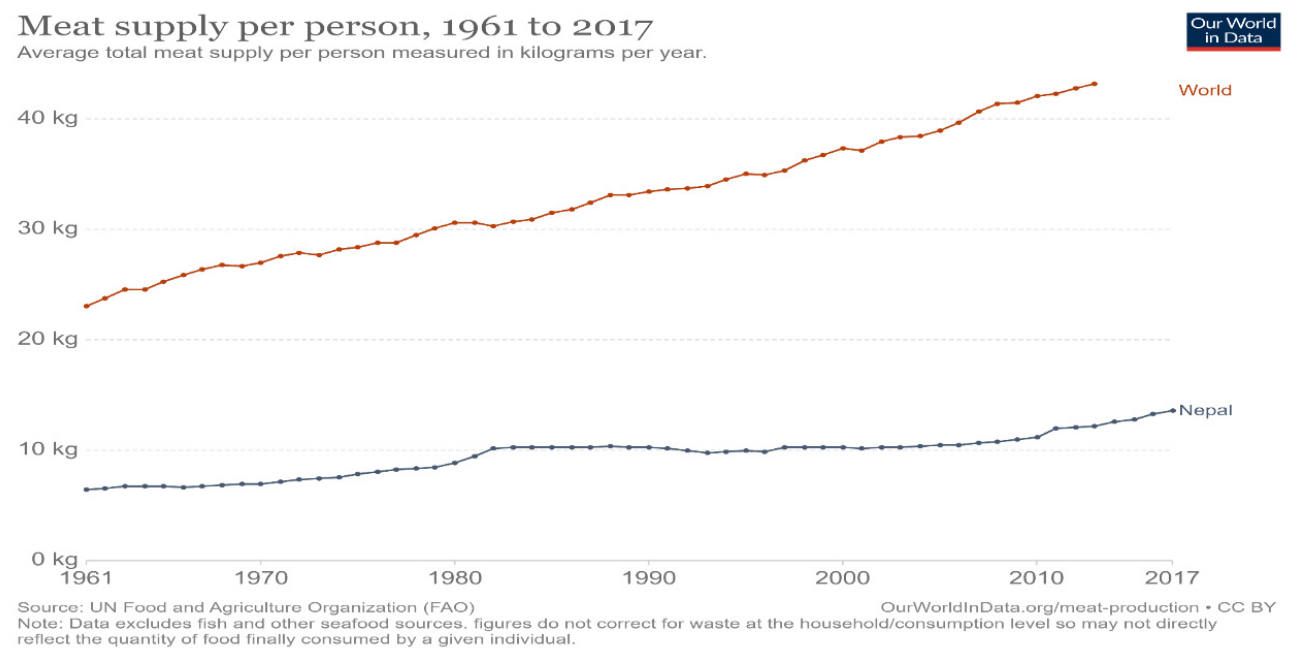

Source: UN Food and Agricultural Organization (Adapted from Ritchie, 2017)

Poultry meat is the second largest consumed meat in the world; the world per capita consumption of poultry meat was $14.99 \mathrm{~kg}$ per year in $2013^{1}$. Figure 2 shows that per capita meat consumption of Nepal is far below the world's average consumption. The per capita meat consumption in Nepal was $12.21 \mathrm{~kg}$ while it was $43.22 \mathrm{~kg}$ for the world in 2013 (Ritchie, 2017). ${ }^{2}$ On the other hand, commercial poultry farm in Nepal produced $4.1 \mathrm{~kg}$ of meat and 44 units of eggs per year per person (CBS, 2016) which is below the global average of $12 \mathrm{~kg}$ of meat and 153 units of eggs respectively. This shows that Nepal not only produces far below the global average but also that there is excess demand of meat in Nepali market. Hence, there is a lot of scope of further growth of poultry farming in Nepal.

\section{THEORETICAL MODEL}

In the process of production, technical efficiency displays the ability of the firm to produce output with minimum loss (Kumbhkar et al., 2015). There can be various technology with different sets of inputs for the desired output. The selection of the best technology is a technical problem (Henderson \& Quandt, 2013). Production function

1 Pork is the highest per capita consumed meat product in the world. According to UN FAO, the consumption of pork was $16.02 \mathrm{~kg}$ per capita in 2013.

2 https://ourworldindata.org/meat-production 
is the prerequisite relation between inputs and outputs. The structure of production function can be defined using different production model. In case of the estimation of the stochastic frontier and technical efficiency, numbers of literature often utilized Cobb-Douglas model (C-D function) or trans-log model (See, for example, Greene, 2008; Mari \& Lohano, 2007; Essilfie et al., 2011). The C-D function can be expressed as follows:

$Y_{i}=f\left(X_{i}\right)$

Where, i represent firms. Equation (1) represents the general formula of the production function. $Y_{i}$ is the output produced and $f\left(X_{i}\right)$ is the inputs process and technology utilized, $X_{\mathrm{i}}$ includes the different quantity of inputs and their organization.

Greene (2008) and Kumbhkar et al. (2015) state that the production function is a mathematical interpretation of the production process and efficiency is the ability to produce higher output utilizing the minimum inputs. If the actual output of the firm is equal to theoretically obtained output, then the firm is $100 \%$ efficient.

Empirical studies show that firms usually produce at the lower than the frontier level. But the neo-classical production theory assumes that the market always correct inefficiencies and that the production activities are carried out at frontier level. However, it could not explain the actual firm situation. The production efficiency literature relaxes this assumption. It consider the possibility that producers may operate below the frontier due to technical inefficiency (Kumbhakar \& Wang, 2010)

Technical efficiency can be estimated using either input oriented or output oriented technical efficiency methods. Input oriented method minimizes input for observed output and output oriented method maximizes the output for the given inputs. We can either use deterministic method such as Corrected ordinary linear system (COLS) and Corrected mean absolute deviation (CMAD) or stochastic method such as SFA (Kumbhakar \& Lovell, 2000).

Technical efficiency is expressed as follows:

$$
\begin{aligned}
& Y_{i}=f\left(X_{i}, \beta\right) \exp \left(-u_{i}\right) \cdots \\
& T E=\exp \left(-u_{i}\right)=\frac{f(X i, \beta)}{Y_{i}}
\end{aligned}
$$


Equation (2) represents deterministic production model. Equation (3) shows technical efficiency derived from equation (2). Negative of $u_{i}\left(-u_{i}\right)$ yields technical inefficiency while exp $\left(-u_{i}\right)$ gives technical efficiency (Kumbhakar \& Lovell, 2000).

A seminal work by Farrell (1957) was the pioneer paper to provide a satisfactory measure of productive efficiency and to demonstrate the practical ways of computing it. Building on that paper, Aigner et al., (1977) and Meeusen and Broeck (1977) utilized the stochastic frontier model (SFM) for the computational purpose. ${ }^{3}$ Non-parametric approach like COLS and CMAD are deterministic. Any shortfall to achieve the potential output, fall onto inefficiency. Deterministic frontier model does not differentiate between random shock and the actual technical inefficiency. It ignores the effects of the random shock like environment, natural disaster on the production process. The error term in the SFM includes the random shock and technical inefficiency. Both error terms together is known as composite error. Here, the frontier of each firm may vary from other and from itself over the time period. This is due to the presence of the random shock. That is why, this model is called as the SFM.

$\operatorname{Ln} Y_{i}=X_{i} \beta+\varepsilon_{i}$

where, $\varepsilon_{i}=v_{i}-u_{i}$

Equation (4) shows the log linear form of the production function. $\varepsilon_{\mathrm{i}}$ represents the composite error, $v_{i}$ is the two-sided error representing the symmetric disturbance. It is independently and identically distributed (iid) i.e., $\left\{\mathrm{N}\left(0,\left(\sigma_{u}^{2}\right)\right)\right\}$ and $\mathrm{v}_{\mathrm{i}}$ is one-sided error point representing the technical inefficiency. It is also independently distributed $\left(u_{i} \geq 0\right)$. The technical inefficiency error term is non-positive disturbance, which reflect the fact that the output cannot raise above its frontier.

One of the significances of the SFM, as already mentioned, is the separation of the technical efficiency from other shocks. However, it is problematic to decompose the compound error $\varepsilon_{i}$ into the two components $u_{i}$ and $v_{i}$ as stated in equation (5). The average of the $\widehat{\varepsilon_{2}}$ helps to estimate the average technical inefficiency but it is desirable

3 An alternative method to estimate the technical efficiency is data envelope analysis (DEA). There are two important reasons of choosing SFM over DEA in this study. One, DEA is a nonparametric approach which does not assume any form of technology and lacks provision of statistical noises. Hence, any deviation in the frontier is attributed to inefficiencies (Greene, 2008). Two, previous researches show that both SFM and DEA models are adversely affected by measurement error when cross-sectional data are used. In other words, only panel data are better suited to handle the statistical noise and measurement error when SFM and DEA models are applied respectively (Ruggiero, 2007). In the absence of panel data, we therefore choose SFM in this study. 
to have the technical inefficiency of each observations (Kumbhakar \& Lovell, 2000). Distribution assumption about the errnr torm help to identify the two error terms. The error term $u_{i}$ is independent of $v_{i} . v_{i}$ is widely accepted to have a zero mean normal distribution. The distribution assumption made helps to derive the technical inefficiency in the production function. Generally used distribution assumptions are: half-normal distribution; truncated- normal distribution; and exponential distribution. The distribution function of each of these types are:

$E\left(\frac{u_{i}}{\varepsilon_{i}}\right)=\frac{\sigma_{*} \Phi\left(\frac{\mu_{i} i}{\sigma_{*}}\right)}{\Phi \frac{\mu_{i} i}{\sigma_{*}}}+\mu_{\mathrm{s}_{\mathrm{i}}}$ (for half-normal and truncated distribution)

$E\left(\frac{u_{i}}{\varepsilon_{i}}\right)=\frac{\sigma \cdot \phi\left(\frac{\mu, i}{\sigma v}\right)}{\Phi\left(\frac{\mu, i}{\sigma v}\right)}+\mu_{u_{i}}$ (for exponential distribution).

These assumptions help to derive the log-likelihood function of the model. Thereafter, using the maximum likelihood method, we estimate the model parameters. A simple test of skewness applied after OLS estimation helps determine the presence of technical inefficiency. The stochastic frontier contains two-error term and equation (5) describes their relationship. If $u_{i}=0$, then $\varepsilon_{i}=v_{i}$. This means that the error is symmetric and there is no technical efficiency. However, if $u_{i} \geq 0$, then $\varepsilon_{i}=v_{i}-u_{i}$ is negatively skewed, this means that there is a presence of technical efficiency. However, the skewness does not consider the distribution pattern. That's why the likelihood ratio test is used to overcome this shortcoming of skewness test. Since the log-likelihood ratio test requires the log-likelihood value of both OLS regression and SFM, we can only calculate the ratio after running the maximum likelihood estimates. It is a long process and this is the only drawback of the log-likelihood ratio method (Kumbhkar et al., 2015).

The estimated value of variance of technical inefficiency $\left(\sigma_{u}^{2}\right)$ is enough to estimate the average technical inefficiency. However, it is not enough to estimate the technical inefficiency of each observation. Jondrow et al. (1982) proposed to estimate the value of $u_{i}$ from the conditinal distribution of $u_{i}$ given $\varepsilon_{i}$. Either mean or mode of the distribution can be used to estimate inefficiency of each observation.

$\varepsilon_{i} \quad$ We can further introduce some exogenous variables to determine technical inefficiency $u_{i}$. Following Kumbhkar et al. (2015) and Resifscneider and Stevenson (1991), $u_{i}$ can also be further expressed as a function of those variables and random compoenents as

$u_{i} \quad$ expressed in equation (8):

$u_{i}=g\left(Z_{i}\right)+w_{i}$ 
Where, $\mathrm{Z}$ is a vector of exogenous determinants of technical inefficiency and $W_{i}$ is its unexplained error component which is assumed iid.

\section{EMPIRICAL REVIEWS}

Reinhard et al. (1999) estimates technical and environmental efficiency of a panel of Dutch dairy farms. Using stochastic translog production frontier to estimate the technical efficiency, the study finds high mean technical efficiency of 89.4 percent concluding that intensive dairy farms are technically efficient than extensive farms. Using primary data collected from sixty small holder tea producers in Sri Lanka, Basnayake and Gunaratne (2002) used C-D specification and translog models for green leaf yield. The mean technical efficiency estimated was 64.60 percent suggesting rooms for improving productivity and profitability of the Sri Lankan tea firms. Likewise, using similar model specifications, Msuya and Ashimogo (2005) show mean technical efficiency between 76.43 percent and 80.65 percent depending upon the type of Sugarcane growers in Tanzania. Binumate et al. (2008) found that producers could increase their production and income by 17.7 percent given the current level of technology and resources in case of Nigeria. Other factors that can help improve technical efficiency is by increasing the level of education and availability of labor.

Todsadee et al. (2012) used SFM to estimate production efficiency of poultry farming in Thailand and showed that the mean technical efficiency is 79 percent. The study further showed that the socio-economic variables like education, age of farmer, access to credit had a positive effect on the efficiency level. As an input, feed cost, bird stock, variable and fixed cost are significant while labor was found to be insignificant. Another study by Ezeh et al. (2012) in Abia State, Nigeria showed low productivity and inefficiency in resource allocation and management. They showed the average efficiency at 75 percent. The efficiency was linked to the production factors i.e. stock size, feed intake, and labor inputs. Likewise, owner's socio-demographic characteristics such as age and education of the owner were also shown to be significant determinants of technical efficiency. Trujillo and Iglesias (2013) studied the causes of deterioration in productivity of pineapple farm in Santander, Colombia. A production frontier with a Cobb-Douglas functional form was utilized with the inputs such as labor, the number of seeds, and the quantity of defensives to determine the efficiency. The study shows that the technical efficiency varies from 11 to 95 percent and all the inputs were significant and the level of education of small farmer was low. Ohajianya et al. (2013), in addition to technical efficiency also calculated eocnomic efficiency of poultry farms in Imo State of Nigeria. Using primary data randomly collected from 140 poultry famers, they estimated technical efficiency of 75 percent and economic efficiency of 21 percent. Another study by Bethel et al. (2016) estimated technical efficiency of poultry farmers in Cross River State, Nigeria at 58 percent. The variables such as feeds, access 
to membership, access to credit, veterinary services, chick, labor, etc. had positive impact on the level of technical efficiency.

Elpawati et al. (2018) studied the poultry layer farm in Malaysia to analyze the issue of high cost of production, obscured pattern of production and efficient use of resources. The study estimated the mean technical efficiency utilizing stochastic production frontier at 88 percent. The study also exploited DEA-bootstrap technique to estimate technical efficiency. The study further stated that improvement in education and production experience among other things have helped decreased the technical inefficiency. Another study by Yenibehit et al. (2019) showed that the number of birds, medication, quality of water, age, contract extension and engagement of the female gender have positive impact on the technical efficiency. Using the data collected from 120 broiler farms in Charsadda district of Khyber Paktunkhwa province in Pakistan, Ullah et al. (2019) estimated the mean technical efficiency at 85 percent.

In Nepal, so far as we understand, there are no studies estimating technical efficiency of poultry farms. Using primary data collected from poultry farms in Chitwan district of Nepal, Osti et al. (2016) conducted an economic analysis of poultry egg production. They showed that the factors like area, family size and number of laying birds play significant role to improve production efficiency. They concluded that large famers have higher profit margins due to mass production of eggs and lower feed conversion rate.

This study is expected to add to the stock of literature on the estimation of technical efficiency in Nepal. There are only limited literature on technical efficiency in Nepal; the literature that use SFM in poultry farming is non-existent.

\section{DATA AND METHOD}

\section{Model Specification}

Based on the theoretical exposition in equations (1) to (6) in section 3, the C-D production model used for estimation is expressed as follows:

$$
\ln Y_{i}=\beta_{0}+\beta_{1} \ln L_{i}+\beta_{2} \ln S_{i}+\beta_{3} \ln F_{i}+\beta_{4} \ln M_{i}+\beta_{5} \ln V_{i}+v_{i}-u_{i} \cdots
$$

Where, $I n Y_{i}$ is the logarithm of the average revenue received from production of meat and egg at district $i \operatorname{InL}_{i}$ is the logarithm of the average man-days labors. $\operatorname{InS}_{i}$ is the logarithm of the average stock of bird. $\mathrm{InF}_{\mathrm{i}}$ is the logarithm of the average expenses for feeding. InM is the logarithm of the medical cost. $\operatorname{InV}_{i}$ is the logarithm of other variable cost. $V_{i}$ is the random systematic error that is exogenous to the owner of the poultry firm and $u_{i}$ represents technical inefficiency. 
Since, our first round of estimation using backward stepwise regression of equation (9) showed that $\operatorname{InM}_{i}$ and $\operatorname{InV}_{i}$ were highly insignificant and therefore we dropped them from the model (Hocking, 1976). The final production model that will be used is then expressed as follows:

$$
\ln Y_{i}=\beta_{0}+\beta_{1} \ln L_{i}+\beta_{2} \ln S_{i}+\beta_{3} \ln F_{i}+v_{i}-u_{i} \ldots \ldots \ldots
$$

For exogenous determinants of technical inefficiency, the functional form of the technical inefficiency is expressed as follows:

$u_{i}=\delta Z_{i}=\delta_{0}+\delta_{1} z_{2 i}+w_{i}$

Where, $z_{1 \mathrm{i}}$ represents the percent of the trained owner and $z_{2 \mathrm{i}}$ represents the percent of the poultry owner with loans ${ }^{4}$ and $W$ is an unexplained component of the inefficiency error which is assumed iid.

The required parameters were then calculated using the maximum likelihood method. The SFA method were then applied following Kumbhkar et al. (2015) and Belotti et al. (2013). We show the step-wise process of used in flow chart of the SFM. For simplicity, we show the step-wise process used for SFA in this study in figure 2.

\section{Figure 2: Flowchart for the Stochastic Frontier Analysis}

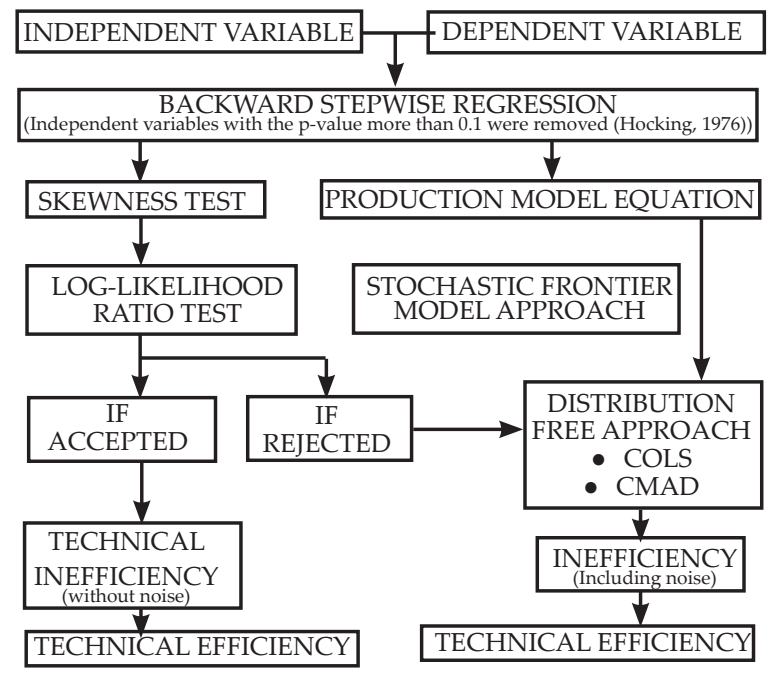

Source: Kumbhkar et al. (2015)

$4 \quad$ In this study, we could not observe the effect of the owner's education and age separately due to the lack of disaggregated data. 


\section{Data and Variables}

The study uses data from the Nepal Commercial Poultry Survey 2015 (NCPS 2015), published by Central Bureau of Statistics (CBS). The stratified sampling framework was used based on National Sample Census of Agriculture 2011/12 where the strata of the firms were prepared as per the number of chickens.

In the first stage, the survey prepares an exhaustive list of all poultry owners across 64 districts and then, in the second stage, it scientifically chooses required number of samples from these districts i.e., the poultry owners for the interview. ${ }^{5}$ This survey includes information on demographic features, status of employment, salary of employees, number of poultry by type, production of meat, chicks and eggs, income by selling meat, eggs and chicks, current and capital expenditure of the firm and other information (CBS, 2016).

We considered district as a unit of analysis. All variables used in the model were aggregated at district level and average was calculated for each of them. The current expenditure was further divided into feeding cost, medicine cost, salary and other cost. Similarly, total labor per district was calculated in mandays and mean number of labor employed per district was estimated for further analysis. ${ }^{6}$

For the study, the total revenue received from the meat and egg was considered as the dependent variable. The independent variables used were: total stock of birds; total man-days labor engaged in the work which includes both family and hired workers in permanent or temporary basis; and feeding cost for the chicken. We dropped medicinal cost and 'other variable costs' from the analysis since it was found to be insignificant in the production function model. As discussed in section 3, we also considered two additional variables, dummy for a trained owner and percent of farm with loan, as exogenous determinants of inefficiency; hence this also accounts for the owner's and the firm's characterstics. Due to data limitations, we could not account for other characteristics of the owner such as age and education.

$5 \quad$ Only 64 out of 75 districts were involved in poultry farming.

6 The report computes temporary labor in the man-days while permanent workers were accounted in numbers of labor. In order to maintain consistency for the purpose of analysis, we calculated the 'total' labour in man-days. We use a standard time of 8 working hours per day as 1 man-day and assumed that each permanent worker works for 285 man-days in a year. 


\section{RESULTS AND DISCUSSION}

This section presents and discusses the results of the analysis.

\section{Test of Technical Inefficiency}

In this section, we first test the null hrmotheses whether there is no technical

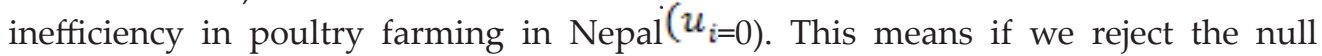
hypotheses, there is technical inefficienry. In order to check it, one of the methods is to estimate the skewness of the term $\widehat{u}_{\imath}$ in equation (8). If the skewness is negative, this means technical inefficiency. However, the limitation of the method of skewness is that the OLS regression used for estimation does not consider the assumption about the distribution. Hence, we use log-likelihood ratio test and consider half-normal, truncated normal and exponential distributions separately. The log-likelihood test depends on the log-likelihood values of the restricted model (OLS) and unrestricted model (Stochastic Frontier Model).

Table 2: Test of Technical Inefficiency using Log-likelihood Ratio Test

\begin{tabular}{|l|l|l|l|}
\hline Method & $\begin{array}{l}\text { Log- } \\
\text { likelihood } \\
\text { value }\end{array}$ & $\begin{array}{l}\text { Log- } \\
\text { Likelihood } \\
\text { ratio (LR) }\end{array}$ & $\begin{array}{l}\text { Degree of } \\
\text { freedom }\end{array}$ \\
\hline OLS method (no distribution assumed) & 25.63 & & \\
\hline Half-normal Distribution & 29.52 & 7.78 & 3 \\
\hline Truncated Normal Distribution & 30.027 & 8.794 & 6 \\
\hline Exponential Distribution & 29.94 & 8.62 & 3 \\
\hline
\end{tabular}

Source: Author's calculation using NCPS 2015 data.

The value obtained from the log-likelihood ratio test is then compared with the mixed chi-squared table given by Kodde and Palm (1986) for various degrees of freedom (dof) shown in Table 2. The mixed chi-squared table is given in Annex 1. The comparison shows that we cannot reject null hypotheses assuming truncated normal distribution while we failed to accept null hypotheses assuming half-normal and exponential distribution. In case of truncated distribution, the calculated log-likelihood ratio is lower than tabulated value while the calculated ratio is higher than the tabulated value in case of half-normal and exponential distributions (at 5 percent level of significance). Hence, we conclude that there is technical inefficiency in the model.

\subsection{Results from Stochastic Frontier Model}

In this sub-section, we present the results from the SFM. Table 3 provides a statistical summary of the SFM assuming exponential distribution. 
Table 3: Estimation Result of Stochastic Frontier Model

\begin{tabular}{|c|c|c|c|c|c|}
\hline & \multirow[t]{2}{*}{ Variables } & \multicolumn{2}{|c|}{ Half-Normal } & \multicolumn{2}{|l|}{ Exponential } \\
\hline & & $\begin{array}{l}\text { Coefficient } \\
\text { (St. Error) }\end{array}$ & $p>|z|$ & $\begin{array}{l}\text { Coefficient } \\
\text { (St. Error) }\end{array}$ & $p>|z|$ \\
\hline \multirow[t]{4}{*}{ Frontier } & Labor (L) & $\begin{array}{c}0.544^{* * *} \\
(0.147)\end{array}$ & 0.000 & $\begin{array}{l}0.55^{* * *} \\
(0.145)\end{array}$ & 0.000 \\
\hline & Stock of Bird (s) & $\begin{array}{l}0.237^{* *} \\
(0.088)\end{array}$ & 0.007 & $\begin{array}{l}0.233^{* *} \\
(0.0865)\end{array}$ & 0.007 \\
\hline & $\begin{array}{c}\text { Feeding } \\
\text { expenses }(\mathrm{F})\end{array}$ & $\begin{array}{l}0.55^{* * *} \\
(0.0825)\end{array}$ & 0.000 & $0.556^{* * *}(0.081)$ & 0.000 \\
\hline & Constant & $\begin{array}{c}1.22 \\
(0.924)\end{array}$ & 0.187 & $\begin{array}{c}1.094 \\
(0.9189)\end{array}$ & 0.234 \\
\hline \multirow[t]{3}{*}{ Usigma $\left(\sigma_{u}\right)$} & Trained owner & $\begin{array}{c}2.98 \\
(2.33)\end{array}$ & 0.201 & $\begin{array}{c}3.545 \\
(2.7431)\end{array}$ & 0.196 \\
\hline & $\begin{array}{l}\text { Percent of farm } \\
\text { with loan }\end{array}$ & $\begin{array}{l}4.237 \\
(2.824)\end{array}$ & 0.134 & $\begin{array}{c}5.731 \\
(4.120)\end{array}$ & 0.164 \\
\hline & Constant & $\begin{array}{c}-7.104^{* *} \\
(2.512)\end{array}$ & 0.005 & $-9.311^{* *}(2.941)$ & 0.002 \\
\hline Vsigma $\left(\sigma_{v}\right)$ & Constant & $\begin{array}{l}-4.242 \\
(0.34)\end{array}$ & 0.000 & $-4.169(0.2666)$ & 0.000 \\
\hline \multicolumn{2}{|c|}{ Log-Likelihood } & \multicolumn{2}{|l|}{29.521} & \multicolumn{2}{|l|}{29.938} \\
\hline \multicolumn{2}{|c|}{ Wald Chi-Square (3) } & \multicolumn{2}{|l|}{548.01} & \multicolumn{2}{|l|}{578.96} \\
\hline \multicolumn{2}{|c|}{ Number of Observations } & \multicolumn{2}{|l|}{64} & \multicolumn{2}{|l|}{64} \\
\hline
\end{tabular}

Source: Authors

Note: ${ }^{* * *} \mathrm{p}<0.01,{ }^{* *} \mathrm{p}<0.05,{ }^{*} \mathrm{p}<0.1$

The coefficients of all the independent variables are positive and significant indicating any increase in labour, stock of bird and the feeding expenses increase the revenue of the poultry firms. This is consistent with other studies such as by Ezeh et al. (2012), Ohajianya et al. (2013) and Ullah et al. (2019); they also found feed cost, labor and stock size as significant determinants of poultry revenues. It can be observed that the labour and the feeding expenses contributes largely to the increase in revenue of the poultry firms. A 100 rupees increase in feeding cost would increase revenue by about 55 rupees. CBS (2016) also shows that the feeding cost occupies the largest proportion of operating expenditure in poulty farms in Nepal. It occupies 67 percent of the recurrent expenditure. Osti et al. (2016) also conclude on similar lines: in their case, feeding cost command $74.03 \%$ of the total variable cost. Similarly, the results also show that the 
increase in labour as well as the stock of bird would also increase the value of output. We do not find any significant effect of trained farmer and credit on production.

Technical inefficiency is estimated using the method purposed by Jondrow et al. (1982). The point estin $\underline{u}_{i}$ te for each observation were estimated using the condition mean of $u_{i}$ given $\varepsilon_{i}\left[E\left(s_{i}\right)\right]$. Technical inefficiency thu $\left(\underline{u_{i}}\right)$ imated were subsequently utilized to estimate the technical efficiency i.e. $\left[\exp \left\{-\mathrm{E}\left(\bar{s}_{i}\right)\right\}\right]$.

Table 4: Estimation of Technical Efficiency and Inefficiency

\begin{tabular}{|l|l|c|c|c|}
\hline \multicolumn{2}{|l|}{ Distribution } & $\begin{array}{c}\text { Mean } \\
\text { (St. Error) }\end{array}$ & Minimum & Maximum \\
\hline $\begin{array}{l}\text { Half-Normal } \\
\text { Distribution }\end{array}$ & Efficiency & $\begin{array}{c}89.07 \% \\
(0.07069)\end{array}$ & $55.22 \%$ & $96.52 \%$ \\
\cline { 2 - 5 } & Inefficiency & $\begin{array}{c}11.94 \% \\
(0.09087)\end{array}$ & $3.54 \%$ & $59.37 \%$ \\
\hline Exponential & Efficiency & $\begin{array}{c}92.15 \% \\
(0.0703)\end{array}$ & $59.58 \%$ & $97.16 \%$ \\
\cline { 2 - 5 } & Inefficiency & $\begin{array}{c}8.5 \% \\
(0.089)\end{array}$ & $2.87 \%$ & $51.77 \%$ \\
\hline
\end{tabular}

Source: Author's calculation using NCPS 2015

Table 4 shows the technical ineffciency of 11.94 and technical efficiency of 89.07 percent assuming half-normal distribution while 8.5 percent inefficeincey and 92.15 percent efficiency respectively assuming exonential distribution. This means that the poultry firms in Nepal produce about 89 to 92 percent of its potential output. This suggests that there is a room to reduce technical inefficiency on average by about 10 percent per cent and improve technical efficiency by 9 percent. $^{7}$

Figure 3 shows technical inefficiency across 64 districts of Nepal assuming exponential distribution. Annex 2 shows the technical efficiency by districts.

$7 \quad$ The difference between the two value is due to the fact that $1-\mathrm{e}^{\mathrm{u}} \sim \mathrm{u}$. U value is very small; therefore there is little different between their readings. 


\section{Figure 3: District-Wise Distribution of Technical Inefficiency}

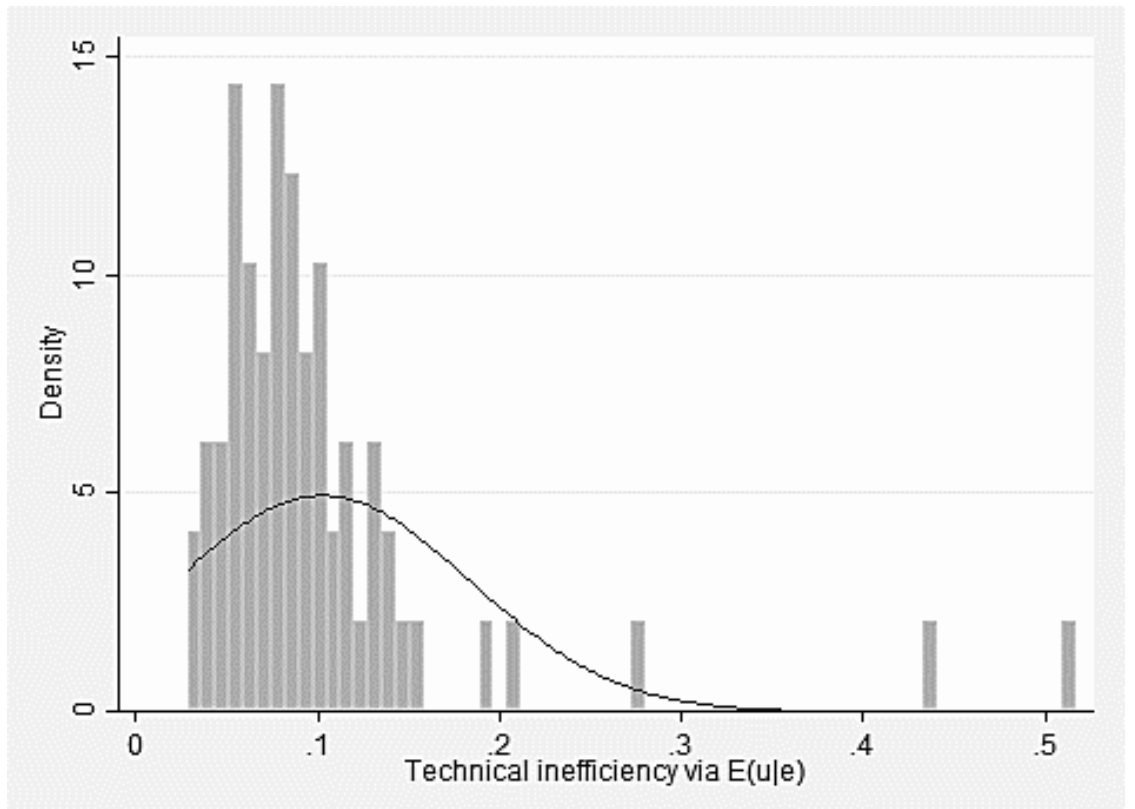

Source: Author's calculation using NCPS 2015

Figur 3 shows that the technical efficiency of commerical poutry farms are relatively high; except for the few observations, most of the observation are concentrated near the point 0.1 . Furthermore, we find that the poultry firms of only 8 districts (13 percent) have technical efficiency greater than 95 percent. Majority (38 percent) have technical efficiency between 90 and 95 percent (See Table 5). This means that there is nealry a homogenous distribution of the technical efficiency across the sampled district.

Table 5: District Level Frequency of Distribution of Technical Efficiency

\begin{tabular}{|l|l|l|}
\hline Efficiency(\%) & Frequency (No. of districts) & Percent \\
\hline 95 and above & 8 & 0.13 \\
\hline $90-95$ & 38 & 0.59 \\
\hline $85-90$ & 13 & 0.20 \\
\hline $80-85$ & 2 & 0.03 \\
\hline $75-80$ & 1 & 0.016 \\
\hline 75 and below & 2 & 0.03 \\
\hline
\end{tabular}

Source: Author's calculation using NCPS 2015 data. 
We also analyzed the percentile of the distribution of technical efficiency and find that the 25th percentiles of technical efficiency is 89.44 percent (see Table 6). This means that 75 per cent of the observation lies around and above the average technical efficiency. Few outlier districts are Rupandehi and Banke whose technical efficiency are 59.58 percent and 64.47 percent resepctively. Hence, with few exceptions, this confirms that the distribution of technical efficiency is homogenous across the sampled districts.

Table 6: District Level Distribution of Technical Efficiency in Percentiles

\begin{tabular}{|c|c|}
\hline Percentiles & Technical Efficiency \\
\hline $1 \%$ & 0.596 \\
\hline $5 \%$ & 0.811 \\
\hline $10 \%$ & 0.866 \\
\hline $25 \%$ & 0.894 \\
\hline $50 \%$ & 0.918 \\
\hline $75 \%$ & 0.941 \\
\hline $90 \%$ & 0.959 \\
\hline $95 \%$ & 0.959 \\
\hline $99 \%$ & 0.972 \\
\hline
\end{tabular}

Source: Author's calculation using NCPS 2015 data.

Finally, we also analyzed the effect of technical efficiency on profit of the firms. CBS (2016) stated that $76 \%$ of poultry farms were running in profit. Figure 4 shows the graphs denoting percent of the firms running in profit in a given district as against the technical efficiency of that district.

Figure 4: District-Wise Relationship between Technical Efficiency and the Firm's Level of Profit

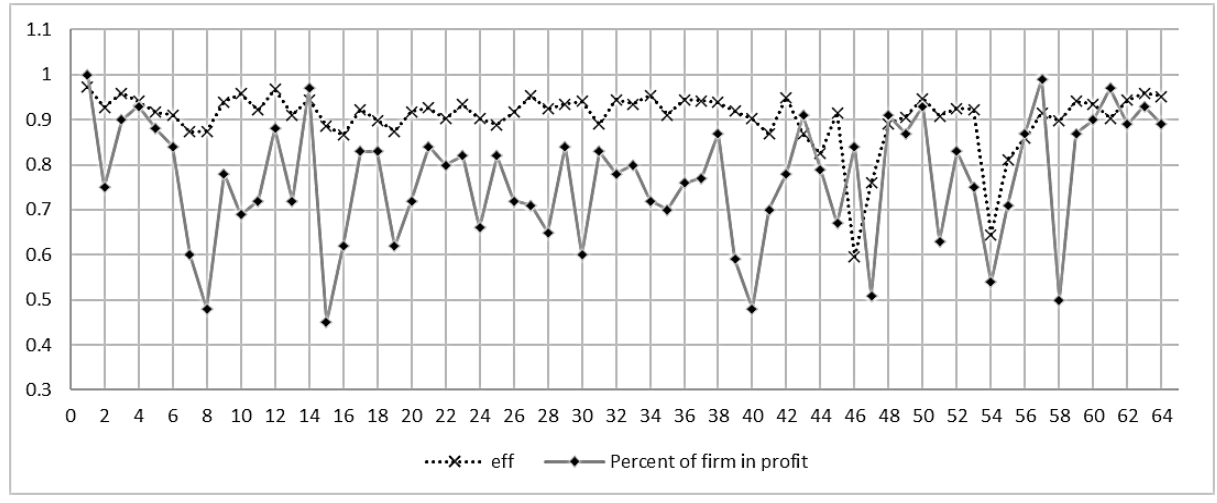

Source: Author's calculation using NCPS 2015 data. 
The figure shows that 76 percent of the firms are running in profit. Districts with higher efficiency had the higher percent of firms running in profit. However, this is not true in all the cases. For example, some districts like Myagdi, Siraha, Terhathum and Bajhang had technical efficiency of 90 percent and above but only 50 percent of the firms were running in profit. Likewise, in other districts like Kapilbastu and Banke where technical efficiency is around 75 percent and 64 percent respectively, only 50 percent of the firm were running in profit. This inconsistency indicates that there are other factors besides efficiency driving firm's level of profit.

Let us now discuss some pathways to high technical efficiency in Nepal poultry farms. One factor may be education. Nearly 80 percent of the poultry farm owners have at least a high school education (CBS, 2016). Likewise, the young age may also have added to the high technical efficiency; nearly 70 percent of the firm owners lie between 25 and 44 years of age. Young and educated workforce are more likely to be aware about the use of technology and the efficient ways of doing poultry farming. Another contributing factor may be the labour working in the farm who are mostly family members. Family workers have a higher sense of ownership and responsibility unlike the workers hired from outside. These factors may also have helped to run the poultry farming at high efficiency.

\section{CONCLUSION}

This study attempts to estimate technical efficiency of poultry farms in Nepal. It also estimates technical efficiency by districts. The study uses SFA method and utilizes maximum likelihood estimator to calculate the technical efficiency. Using data from Nepal Commercial Poultry Survey 2014/15, the study estimates technical efficiency equivalent to 90 and 92 percent assuming half-normal and epoenntial distribution of the error terms in the production model respectively. This means that on average the poultry firm in Nepal produces about 91 percent of the maximum (potential) output and that it could be further improved by 10 percent. Except for the few outliers like Rupandehi district, the technical efficiency estimated spatially across the districts showed its nearly homogenous distribution. Furthermore, the regression estimates of the production model shows that labor and feeding cost were significant determinants of the production of the firm.

Given that the poultry industry in Nepal contributes about 8 perent of agricultural GDP of the country, it is now an important source of rural livelihood (Kattel, 2016). Hence, the government has to give particular attention to increase the productivity of this sector. Our study points out that feeding cost is one of the major determinants; hence, in order to attain some economies of scale, necessary plan and strategies to increase both the quality and quantity of feed by providing necessary financial and 
technical support may be helpful. It might also be necessary to understand the efficacy of particular quality of feed in the particular type of environment. For example, the growth of the birds may vary in different temperature and/or altitude as a response to the similar quality and dose of the feed. This, to some extent, is also explained in the findings of our study where some districts had low technical efficiency while few others had sufficiently low technical efficiency.

The supply of quality birds/chicks, as pointed out by our study, is also important to improve productivity. Hence, in order to ensure the regular supply of quality chicks, it is imperative to increase the supply of hatcheries. CBS (2016) reports that there are only 128 hatcheries across the country spread in one-third of the total districts and most of them are concentrated in urban areas. Since poultry farming contributes largely to rural population, necessary support should be provided to establish new hatcheries in rural areas.

FAO (2014) identifies poor knowledge of poultry farmers, poor quality standards, weak enforcement of rules, regulations and guidelines, lack of regular sero-monitoring, disease diagnosis and prevention mechanims as some of the factors restraining the proper growth of poutry industry in Nepal. Hence, implementing and supervising quality checks of feed ingredients, vaccine, chicks and other related products can be helpful in this regard.

Generally, technical training provided to the farmers have a significant positve effect on productivity growth. On the contrary, in our study, we find no effect of training. Hence, it might be useful to undertake further study to identify the reasons for this. This will guide concerned agencies revisit and revise the training manuals/modules and approaches used towads it. Similarly, this study could not control several other variables such as age and education of the poultry farmers due to data limitations. Hence, it might be worthwhile to conduct a separate farm-level analysis to understand the effect of sociodemographics on productivity of poultry farms. 
Annexes

Annex 1: Critical Values of Mixed Chi-squared Distribution

\begin{tabular}{|c|c|c|c|c|c|c|c|}
\hline $\mathrm{df} / \alpha$ & 0.25 & 0.1 & 0.05 & 0.025 & 0.01 & 0.005 & 0.001 \\
\hline 1 & 0.455 & 1.642 & 2.706 & 3.841 & 5.412 & 6.635 & 9.5 \\
\hline 2 & 2.090 & 3.808 & 5.138 & 6.283 & 8.273 & 9.634 & 12.810 \\
\hline 3 & 3.475 & 5.528 & 7.045 & 8.542 & 10.501 & 11.971 & 15.357 \\
\hline 4 & 4.776 & 7.094 & 8.542 & 10.501 & 12.483 & 14.045 & 17.612 \\
\hline 5 & 6.031 & 8.574 & 10.371 & 12.103 & 14.325 & 15.968 & 19.696 \\
\hline 6 & 7.257 & 9.998 & 11.911 & 13.742 & 16.074 & 17.791 & 21.666 \\
\hline 7 & 8.461 & 11.383 & 13.401 & 15.321 & 17.755 & 19.54 & 23.551 \\
\hline 8 & 9.648 & 12.737 & 14.853 & 16.856 & 19.384 & 21.232 & 25.370 \\
\hline 9 & 10.823 & 14.067 & 16.274 & 18.354 & 20.972 & 22.879 & 27.133 \\
\hline 10 & 11.987 & 15.377 & 17.670 & 19.824 & 22.525 & 24.488 & 28.856 \\
\hline
\end{tabular}

Source: Kodde \& Palm (1986)

Annex 2: Technical Efficiency by Districts

\begin{tabular}{|l|c|c|}
\hline District & Technical inefficiency & Technical efficiency \\
\hline Taplejung & 0.029 & 0.972 \\
\hline Panchthar & 0.075 & 0.928 \\
\hline Ilam & 0.041 & 0.960 \\
\hline Jhapa & 0.061 & 0.941 \\
\hline Morang & 0.087 & 0.917 \\
\hline Sunsari & 0.093 & 0.911 \\
\hline Dhankuta & 0.135 & 0.874 \\
\hline Terhathum & 0.134 & 0.875 \\
\hline Sankhuwasabha & 0.062 & 0.940 \\
\hline Bhojpur & 0.044 & 0.957 \\
\hline Okhaldhunga & 0.082 & 0.921 \\
\hline Khotang & 0.033 & 0.968 \\
\hline Udayapur & 0.094 & 0.910 \\
\hline Saptari & 0.057 & 0.944 \\
\hline Siraha & 0.121 & 0.886 \\
\hline Dhanusa & 0.144 & 0.866 \\
\hline Mahotari & 0.080 & 0.923 \\
\hline Sarlahi & 0.107 & 0.899 \\
\hline Sindhuli & 0.134 & 0.875 \\
\hline
\end{tabular}




\begin{tabular}{|l|l|l|}
\hline Ramechhap & 0.086 & 0.918 \\
\hline Dolakha & 0.077 & 0.926 \\
\hline Sindhupalchok & 0.104 & 0.902 \\
\hline Kavrepalanchok & 0.069 & 0.934 \\
\hline Lalitpur & 0.103 & 0.902 \\
\hline Bhaktapur & 0.118 & 0.889 \\
\hline Kathmandu & 0.087 & 0.917 \\
\hline Nuwakot & 0.048 & 0.953 \\
\hline Rasuwa & 0.079 & 0.924 \\
\hline Dhading & 0.067 & 0.935 \\
\hline Makwanpur & 0.061 & 0.941 \\
\hline Rautahat & 0.116 & 0.891 \\
\hline Bara & 0.058 & 0.944 \\
\hline Parsa & 0.068 & 0.935 \\
\hline Chitawan & 0.047 & 0.954 \\
\hline Gorkha & 0.093 & 0.911 \\
\hline Lamjung & 0.057 & 0.945 \\
\hline Tanahu & 0.059 & 0.942 \\
\hline Syangja & 0.063 & 0.939 \\
\hline Kaski & 0.085 & 0.919 \\
\hline Myagdi & 0.104 & 0.902 \\
\hline Parbat & 0.142 & 0.868 \\
\hline Baglung & 0.053 & 0.949 \\
\hline Gulmi & 0.142 & 0.868 \\
\hline Palpa & 0.192 & 0.825 \\
\hline Nawalparasi & 0.088 & 0.916 \\
\hline Rupandehi & 0.518 & 0.596 \\
\hline Kapilbastu & 0.275 & 0.760 \\
\hline Arghakhanchi & 0.115 & 0.891 \\
\hline Pyuthan & 0.099 & 0.905 \\
\hline Rolpa & 0.054 & 0.947 \\
\hline Rukum & 0.097 & 0.908 \\
\hline Salyan & 0.078 & 0.925 \\
\hline Dang & 0.081 & 0.922 \\
\hline Banke & 0.439 & 0.645 \\
\hline Bardiya & 0.209 & 0.858 \\
\hline Surkhet & 0.153 & \\
\hline & & \\
\hline & & \\
\hline
\end{tabular}




\begin{tabular}{|l|l|l|}
\hline Dailekh & 0.088 & 0.916 \\
\hline Bajhang & 0.108 & 0.898 \\
\hline Doti & 0.060 & 0.941 \\
\hline Kailali & 0.068 & 0.934 \\
\hline Kanchanpur & 0.102 & 0.903 \\
\hline Dadeldhura & 0.058 & 0.944 \\
\hline Baitadi & 0.042 & 0.959 \\
\hline Darchula & 0.049 & 0.952 \\
\hline
\end{tabular}

Source: Author's calculation using NCPS 2015 data.

\section{REFERENCES}

Aigner, D., Lovell, C. K., \& Schmidt, P. (1977). Formulation and estimation of stochastic frontier production function models. Journal of Econometrics, 6(1), 21-37. doi:10.1016/0304-4076(77)90052-5

Basnayake, B., \& Gunaratne, L. (2002). Stimation of technical efficiency and it's determinants in the Tea Small Holding Sector in the Mid Country Wet Zone of Sri Lanka. Sri Lanka Journal of Agricultural Economics, 4(1), 137-150.

Belotti, F., Daidone, S., Ilardi, G., \& Atella, V. (2013). Stochastic frontier analysis using Stata. The Stata Journal, 13(4), 719-758. doi:10.1177/1536867X1301300404

Bethel, E., Fani, D. R., \& Odufa, E. M. (2016). Analysis of technical efficiency of poultry farmers in cross river state, Nigeria. International Journal of Research Studies in Agricultural Sciences, 2(4), 40-45. doi:10.20431/2454-6224.0204005

Binuomote, S. O., Ajetomobi, J. O., \& Ajao, A. O. (2008). Technical efficiency of poultry egg producers in Oyo State of Nigeria. International Journal of Poultry Science, 7(12), 1227-1231. doi:10.3923/ijps.2008.1227.1231

CBS. (2016). Nepal commercial poultry survey 2071/72. Thapathali, Kathmandu: Central Bureau of Statistics (CBS). Retrieved from https://cbs.gov.np/nepalcommercial-poultry-survey-2071-072/

Coelli, T., \& Battese, G. (1996). Identification of factors which influence the technical inefficiency of Indian farmer. Australian Journal of Agricultural Economics, 40(2), 103-128. doi:10.22004/ag.econ.22395

Davey, A. (1948). "Efficiency"-A "must" in poultry production. World's Poultry Science Journal, 4(1), 36-45. doi:10.1079/WPS19480011 
Elpawati, Gabdo, B. H., Ismail, M. M., \&Abdurofi, I. (2018). Stochastic frontier production function and efficiency status of poultry layer farms in Malaysia. International Journal of Poultry Science, 17(12), 568-577. doi:10.3923/ijps.2018.568.577

Essilfie, F., Asiamah, M., \& Nimoh, F. (2011). Estimation of farm level technical efficiency in small scale maize production in the Mfantseman municipality in the central region of Ghana: A stochastic frontier approach. Journal of Development and Agricultural Economics, 3(14), 645-654.

Ezeh, C. I., Anyiro, C. O., \& Chukwu, J. A. (2012). Technical efficiency in poultry broiler production in Umuahia capital territory of Abia State, Nigeria. Greener Journal of Agricultural Sciences, 2(1), 001-007.

FAO. (2014). Poultry sector Nepal. FAO animal production and health livestock country reviews. No. 8. Rome.

Farrell, M. (1957). The measurement of productive efficiency. Journal of the Royal Statistical Society: Series A (General), 120(3), 253-281.

Greene, W. H. (2008). The econometric approach to efficiency analysis. In H. O. Fried, C. K. Lovell, S. S. Schmidt, H. O. Fried, C. K. Lovell, \& S. S. Schmidt (Eds.), The Measurement of Production Efficiency and Productivity Change (pp. 92-159). New York: Oxford University Press. doi:10.1093/acprof:oso/9780195183528.0 03.0002

Henderson, J. M., \& Quandt, R. E. (2013). The theory of the firm. In J. M. Henderson, \& R. E. Quandt, Microeconomic theory: A mathematical approach (2003 ed., pp. 64-103). p-24, Green Park Extension, New Delhi, India: McGraw Hill Education(India) Private Limited.

Hocking, R. R. (1976). A biometrics invited paper. The analysis and selection of variables in linear regression. Biometrics, 32(1), 1-49. doi:10.2307/2529336

Jondrow, J., Lovell, C. K., Materov, I. S., \& Schmidt, P. (1982). On the estimation of technical inefficiency in the stochastic frontier production function model. Journal of Econometrics, 19(2-3), 233-238. doi:10.1016/0304-4076(82)90004-5

Kattel, P. (2016). Socio-economic importance of indigenous poultry in Nepal. Poultry Fish Wildlife Science, 4, 153.

Kodde, D. A., \& Palm, F. C. (1986). Wald criteria for jointly testing equality and inequality restrictions. Econometrica, 54(5), 1243-1248. doi:10.2307/1912331

Kumbhakar, S. C., \& Lovell, C. K. (2000). The estimation of technical efficiency. In S.C. Kumbhakar, \& C. K. Lovell, Stochastic Frontier Analysis (pp. 63-130). Cambridge: Cambridge University Press. doi:10.1017/CBO9781139174411 
Kumbhakar, S. C., \& Wang, H.-J. (2010). Estimation of technical inefficiency in production frontier models using cross-sectional data. Indian Economic Review, 45(2), 7-77.

Kumbhkar, S. C., Wang, H.-J., \& Horncastle, A. P. (2015). A practitioner's guide to stochastic frontier analysis using Stata. 32 Avenue of the Americas, New York, NY 10013-2473, USA: Cambridge University Press.

Mari, F., \& Lohano, H. (2007). Measuring production function and technical efficiency of onion, tomato and chillies farms in Sindh, Pakistan. The Pakistan Development Review, 1053-1064.

Meeusen, W., \& Broeck, J. V. (1977). Efficiency estimation from Cobb-Douglas production function with composed error. International Economic Review, 18(2), 435-444. doi:10.2307/2525757

MoALC. (2018). Statistical information on Nepalese agriculture 2073/74(2016/17). Kathmandu: Ministry of Agriculture, Land Management and Cooperatives (MoALC), Government of Nepal.

Msuya, E., \& Ashimogo, G. (2005). Estimation of technical efficiency in Tanzanian sugarcane production: A case study of Mtibwa Sugar Estate Outgrowers Scheme (MPRA Working Paper 3747). Retrieved from https://mpra.ub.uni-muenchen. de/3747/1/MPRA_paper_3747.pdf

Ohajianya, D., Mgbada, J., Onu, P., Enyia, C., Henri-Ukoho, A., Ben-Chendo, N., \& Godson-Ibeji, C. (2013). Technical and economic efficiencies in poultry production in Imo State, Nigeria. American Journal of Experimental Agriculture, 927-938. doi:10.9734/AJEA/2013/4089

Osti, R., Zhou, D., Singh, V., Bhattarai, D., \& Chaudhary, H. (2016). An economic analysis of poultry egg production in Nepal. Pakistani Journal of Nutrition, 15(8), 715-724. doi:10.3923/pjn.2016.715.724

Palmer, S., \& Torgerson, D. (1999). Economic notes: Definition of efficiency. BMJ Clinical Research, 318, 1136. doi:10.1136/bmj.318.7191.1136

Reinhard, S., Lovell, C., \& Thiissen, G. (1999). Econometric estimation of technical and environmental efficiency: An application to Dutch Dairy Farms. American Journal of Agricultural Economics, 81(1), 44-60.

Ritchie, H. (2017). Meat and dairy production. Our World in Data. Retrieved from https://ourworldindata.org/meat-production

Ruggiero, J. (2007). A comparison of DEA and the stochastic frontier model using panel data. International Transactions in Operational Research, 14(3), 259-266. 
Todsadee, A., Kameyama, H., Ngomsomuk, K., \& Yamauchi, K.-e. (2012). Production efficiency of broiler farming in Thailand: A stochastic frontier approach. Journal of Agriculture Science, 4(12), 221-231. doi:10.5539/jas.v4n12p221

Trujillo, J. C., \& Iglesias, W. J. (2013). Measurement of the technical efficiency of the small pineapple farmer from Santander, Colombia: A stochastic frontier approach. Brazilian Journal of Rural Economy and Sociology (Revista de Economia e Sociologia Rural-RESR), Rural, 51(Suppl), 1-14. doi:10.22004/ag.econ.184562

Ullah, I., Ali, S., Khan, S. U., \& Sajjad, M. (2019). Assessment of technical efficiency of open shed broiler farms: The case study of Khyber Pakhtunkhwa Province Pakistan. Journal of the Saudi society of Agriculture Sciences, 361-366. doi:https:// doi.org/10.1016/j.jssas.2017.12.002

Yenibehit, N., Murshed, M., \& Islam, M. (2019). Assessment of technical efficiency of layer production in Mampong Municipality: Stochastic frontier approach. Current Research in Agriculture Sciences, 6(1), 20-28. doi:10.18488/ journal.68.2019.61.20.28

Zeeshan, H. S., \& Sharma, S. (2018). A production efficiency of input uses in the Indian carpet industry: Stochastic frontier approach. International Journal of Human Resource Management and Research, 8(6), 11-22. 